1 Department of Health. The health of the nation: a strategy for health in England. London: HMSO, 1992

2 Marmot MG, McDowall M. Mortality decline and widening social inequalities. Lancet 1986;ii:274-6.

3 Marmot MG, Shipley MJ, Rose G. Inequalities in death --specific explanations of a general pattern? Lancet 1984;i:1003-6.

4 Marmot MG, Davey Smith G, Stansfeld S, Patel C, North F, Head J, it al. Health inequalities among British civil servants: the Whitehall II study. Lancet 1991;337:1387-93.

5 Goldblatt P. Longitudinal study: mortality and social organisation. London HMSO, 1990. (Series LS, No 6.)

6 Britton M, Fox A, Goldblatt P, Jones DR, Rosato M. The influence of socioeconomic and environmental factors on geographic variation in mortality. In: Britton M, ed. Morality and geography. A rerices in the mid-1980s, England and Wales. London: HMSO, 1990:58-78.

7 Carstairs V, Morris R. Deprivation and health in Scotland. Aberdeen: Aberdeen University Press, 1991.

8 Townsend P, Phillimore P, Beattie A. Health and deprivatim. Inequality and the north. London: Croom Helm, 1988

9 Jarman B. Identification of underprivileged areas. BMF 1983;286:1705-9.

9a Universities of Durham, Edinburgh, Salford. Small area statistics package SASPAC user manual. Vols I and III. Manchester: University of Manchester Computer Centre, 1989

10 Johnson K, Callum C, Killoran A. Appendix 1. In: Johnson K, Callum C, Killoran A, eds. The smoking epidemic. London: Health Education Authority, 1991.

11 Pocock SJ, Cook DG, Shaper AG. Analysing geographic variation in cardiovascular mortality: methods and results. Fournal of the Royal Statistical Society 1982;145:313-41.

12 Pocock SJ, Cook DG, Beresford SAA. Regression of area mortality rates on explanatory variables: what weighting is appropriate? Applied Statistics 1981;30:286-95.

13 Carstairs V, Morris R. Deprivation: explaining differences in mortality between Scotland and England and Wales. BMF 1989;299:886-9.

14 Black D. Inequalities in Health. Report of a research working group. London: Department of Health and Social Security, 1980.

15 Davey Smith G, Bartley M, Blane D. The Black report on socioeconomic inequalitics in health 10 years on. BMF 1990;301:373-7.

16 Mackenbach JP, Bouvier-Colle MH, Jougla E. "Avoidable" mortality an health services: a review of aggregate data studies. $\mathcal{F}$ Epidemiol Community Health 1990;44:106-11.

17 Johnson Z, Jennings S, Fogarty J, Johnson H, Lyons R, Doorley P, et al.
Behavioural risk-factors among young adults in small areas with highmortality versus those in low-mortality areas. Int $f$ Epidemiol 1991;20: 989-96.

18 Haan M, Kaplan GA, Camacho T. Poverty and health. Prospective evidence from the Alameda County study. Am $\mathcal{f}$ Epidemiol 1987;125:989-98

19 Smith SJ. Health status and the housing system. Soc Sci Med 1990;31:753-62.

20 Ross A, Collins M, Sanders C. Upper respiratory tract infection in children, domestic temperatures, and humidity. I Epidemiol Community Health 1990;44:142-6.

21 Pocock SJ, Shaper AG, Cook DG, Packham RF, Lacey RF, Powell P, et al. British regional heart study: geographic variations in cardiovascular mortality, and the role of water quality. BMF 1980;280:1243-9.

22 Elliott P, Hills M, Beresford J, Kleinschmidt I, Jolley D, Pattenden S, et at. Incidence of cancers of the larynx and lung near incinerators of waste solvents and oils in Great Britain Lancet 1992:339:854-7.

23 Graham H. Women's smoking and family health. Soc Sci Med 1987;25:47-56.

24 Smoking. In: General Household Survey 1982: an interdeparmental survey sponsored by the Central Statistical Office. London: HMSO, 1984:189-202.

25 Phillimore PR, Morris D. Discrepant legacies: premature mortality in two industrial towns. Soc Sci Med 1991;33:139-52.

26 Payne JN, Coy J, Milner PC, Patterson S. Are deprivation indicators a proxy for morbidity? A comparison of the prevalence of arthritis, depression, dyspepsia, obseity and respiratory symptoms with unemployment rates and jarman scores. I Public Health Med 1993;15:161-70.

27 Blane D, Davey Smith G, Bartley M. Social class differences in years of potential life lost: size, trends, and principal causes. BMF 1990;301:429-32.

28 Robine JM, Ritchie K. Healthy life expectancy: evaluation of global indicato of change in population health. $B M 71991 ; 302: 457-60$.

29 Mohan J, Killoran A, Johnson K, McKenzie J. Reducing coronary hear disease in England: targets and implications. Health Education foumal 1990;49:176-80.

30 Barker DJP, Osmond C. Infant mortality, childhood nutrition, and ischaemic heart disease in England and Wales. Lancet 1986;: 1077-81.

31 Ben-Shlomo Y, Davey Smith G. Deprivation in infancy or in adult life: which is more important for mortality risk? Lancet 1991; 337:530-5.

32 Egolf B, Lasker J, Wolf S, Potvin L. The Roseto effect: a 50-year comparison of mortality rates. Am f Public Health 1992;82:1089-92.

33 Ashton J. Healthy cities. Milton Keynes: Open University Press, 1992

$34 \mathrm{Mr}$ Major's Dream: is social mobility enough? [Editorial.] Lancet 1990;336: $1547-8$

(Accepted 17 August 1993)
Section of Preventive

Cardiology, Department of

Medicine, Ostra Hospital,

University of Gothenburg,

Sweden

Annika Rosengren, senior

registrar

Lars Wilhelmsen, head of

department

National Institute for

Psychosocial Factors and

Health, Karolinska

Institute, Stockholm,

Sweden

Kristina Orth-Gomér,

professor

Nordic School of Public

Health, Gothenburg.

Sweden

Hans Wedel, professor

Correspondence to:

Dr A Rosengren,

Department of Medicine,

Östra Hospital, S-416 85

Gothenburg, Sweden.

BMf 1993;3071102-5

\title{
Stressful life events, social support, and mortality in men born in 1933
}

\author{
Annika Rosengren, Kristina Orth-Gomér, Hans Wedel, Lars Wilhelmsen
}

\section{Abstract}

Objective-To examine relations between stressful life events and mortality in middle aged men.

Design-Prospective population study. Data on stressful life events, social network, occupation, and other psychosocial factors derived from self administered questionnaires. Mortality data obtained from official registers.

Setting-City of Gothenburg, Sweden.

Subjects-752 men from a random population sample of 1016 men aged 50 .

Main outcome measure-Mortality from all causes during seven years' follow up.

Results-Life events which had occurred in the year before the baseline examination were significantly associated with mortality from all causes during seven years' follow up. Of the men who had experienced three or more events during the past year $10.9 \%$ had died compared with $3.3 \%$ among those with no life events (odds ratio $3.6 ; 95 \%$ confidence interval 1.5 to $8 \cdot 5$ ). The association between recent life events and mortality remained true after smoking, self perceived health, occupational class, and indices of social support were controlled for. Many of the deaths were alcohol related, but the number of deaths was too small to allow for analyses of specific causes of death. The association between life events and mortality was evident only in men with low emotional support.

Conclusion-Stressful life events are associated with high mortality in middle aged men. Men with adequate emotional support seem to be protected.

\section{Introduction}

Psychosocial factors influence mortality. ${ }^{1-8}$ Poor social network, ${ }^{1-4}$ low socioeconomic status, ${ }^{56}$ low social activity, ${ }^{7}$ and bereavement ${ }^{8}$ have all been associated with increased death rates in prospective studies. The concept of emotional stress enters either implicitly or explicitly into most of this research. When examined in epidemiological and clinical investigations life stress may be defined as the numerical accumulation of major life events. ${ }^{9}$ Stress may result either from stressful events in themselves or the person's perception of them. Social support has been suggested to moderate the impact of stress through a buffering effect. ${ }^{1011}$

Life events as a measurement of external life stress was a predominant feature in the research on the influence of stress one or two decades ago. ${ }^{12}$ Early retrospective studies showed adverse life events to be related to various forms of ill health, ${ }^{13-16}$ but prospective studies have yielded conflicting results. ${ }^{17-25}$ Most studies have been conducted in selected populations, and not many have used mortality from all causes as an end point. In recent years interest has shifted towards other psychosocial factors as sources of stress.

To assess the impact of life events on mortality we have investigated data from a cardiovascular survey in middle aged men. In addition to conventional cardiovascular risk factors, the study protocol included questions on several psychosocial factors. Our main hypothesis was that life events predict mortality. In a secondary analysis we investigated whether the potential effect of life events on mortality varied according to level of social support.

\section{Subjects and methods} STUDY POPULATION

In 1983 a random sample was drawn of half of all men in Gothenburg who were born in $1933 .{ }^{26}$ The 1016 men in the sample, all of whom were 50 years old, were invited to a health examination; 776 men $(76 \%)$ responded. 
EXAMINATIONS

Physical and laboratory investigations have been described previously. ${ }^{26}$ Before the examination all participants had completed a postal questionnaire dealing with smoking habits, physical activity during leisure time, and psychological stress. The answers were checked by the examining physician. Physical activity in leisure time was coded as sedentary or other (at least regular walking or gardening). Heavy psychological stress (defined as feeling tense, irritable, or nervous because of conditions at work or at home) was considered to be present if graded 5 or 6 on a scale of 1 to 6 (a permanent feeling of stress during either the past year or the past five years)..$^{27}$

During the examination the participants completed a detailed questionnaire about social variables. Twenty four men did not fill in the questionnaire and were excluded from further analysis. The questionnaire included 10 different life event items $\mathrm{s}^{28}$ and whether the events had occurred the year before the examination, before the previous year, or never. (See table II for details of the separate events.) Life events occurring during the year before the examination were added into a graded scale of none, one, two, or three events or more.

For the measurement of social support a condensed version of the interview schedule for social interaction was used. ${ }^{29}$ This instrument yields two scales describing deep emotional relationships or "emotional support" on one hand and the more peripheral contacts of social networks and "social integration" on the other. For the purpose of the present study both scales were divided into low and high, with low defined as the lowest quarter of the distribution. ${ }^{30}$

The men were also asked about activities during the previous year, ${ }^{7}$ self perceived health, and size of household. Activities were divided into activities at home, activities outside the home, and social activities. Activity scales were derived from adding up the responses coded as 0,1 , and 2 (never, occasionally, or often/regularly). ${ }^{26}$ Self perceived health was rated on a scale with seven ratings ranging from 1 (excellent, could not be better) to 7 (very poor).

Occupation was coded according to the socioeconomic classification system elaborated by the central bureau of statistics in Sweden. In its aggregated form this classification consists of five occupational classes from 1 (unskilled and semiskilled workers) to 5 (professionals, higher civil servants, executives). ${ }^{3132}$ For the purpose of our study men not classifiable by this system (mostly men with disability pensions) were coded as zero and included in the analyses.

\section{FOLLOW UP PROCEDURES}

After a follow up period of seven years, ending on 30 June 1991, mortality was ascertained through official registers. There were 41 deaths among the 752 men who had answered the questionnaire. Five men had emigrated and were considered to be alive. All death certificates were traced. Deaths related to use of alcohol were defined as death from alcoholism, alcohol poisoning, epileptic seizures due to alcohol abuse,

TABLE I-Mortality during follow up by number of recent life events. Figures are percentages (numbers of deaths)

\begin{tabular}{|c|c|c|c|c|c|}
\hline Cause of death & $\begin{array}{l}\text { Coronary heart } \\
\text { disease }\end{array}$ & Cancer & $\begin{array}{l}\text { Alcohol } \\
\text { related }\end{array}$ & $\begin{array}{l}\text { Other } \\
\text { causes }\end{array}$ & Total \\
\hline \multicolumn{6}{|l|}{ Events: } \\
\hline $0(\mathrm{n}=331)$ & $1.5(5)$ & $0.6(2)$ & $0 \cdot 6(2)$ & $0 \cdot 6(2)$ & $3 \cdot 3(11)$ \\
\hline $1(n=210)$ & $1.9(4)$ & $0.5(1)$ & $1 \cdot 0(2)$ & $1.9(4)$ & $5 \cdot 2(11)$ \\
\hline $2(n=110)$ & $0.9(1)$ & $2 \cdot 7(3)$ & $2 \cdot 7(3)$ & $0 \cdot 9(1)$ & $7 \cdot 3(8)$ \\
\hline 3 or more $(n=101)$ & $3.0(3)$ & $2 \cdot 0(2)$ & $3 \cdot 0(3)$ & $3.0(3)$ & $10.9(11)$ \\
\hline $\begin{array}{l}\text { Odds ratio }(95 \% \\
\text { confidence interval }) \\
(0 v 3 \text { or more })\end{array}$ & $2.0(0.5$ to 8.5$)$ & $3.3(0.5$ to 23.9$)$ & $5.0(0.6$ to 30.6$)$ & $5.0(0.8$ to 30.6$)$ & $3.6(1.5$ to 8.5$)$ \\
\hline
\end{tabular}

${ }^{\star}$ See methods for definition.
TABLE II-Mortality from all causes by recent life events during seven years' follow up

\begin{tabular}{|c|c|c|c|}
\hline Life event & $\begin{array}{l}\text { No of } \\
\text { men }\end{array}$ & $\begin{array}{l}\%(\mathrm{No}) \\
\text { of men who } \\
\text { died }\end{array}$ & $\begin{array}{c}\text { Odds ratio } \\
\text { (95\% confidence } \\
\text { interval) (recent } \\
\text { event: no event) }\end{array}$ \\
\hline \multicolumn{4}{|c|}{ Serious illness in family member: } \\
\hline No & 359 & $4 \cdot 5(16)$ & \multirow{3}{*}{$2 \cdot 1(0 \cdot 9$ to $4 \cdot 6)$} \\
\hline Yes, before last year & 269 & $5 \cdot 2(14)$ & \\
\hline Yes, last year & 124 & $8.9(11)$ & \\
\hline \multicolumn{4}{|c|}{ Serious concern about family member: } \\
\hline No & 351 & $3 \cdot 7(13)$ & \multirow{3}{*}{$2 \cdot 3(1 \cdot 1$ to $4 \cdot 8)$} \\
\hline Yes, before last year & 159 & $5 \cdot 0(8)$ & \\
\hline Yes, last year & 242 & $8 \cdot 3(20)$ & \\
\hline \multicolumn{4}{|l|}{ Death of family member: } \\
\hline No & 195 & $6 \cdot 7(13)$ & \multirow{3}{*}{$0.6(0.2$ to $1 \cdot 8)$} \\
\hline Yes, before last year & 439 & $5 \cdot 2(23)$ & \\
\hline Yes, last year & 118 & $4 \cdot 2(5)$ & \\
\hline \multicolumn{4}{|l|}{ Divorce or separation: } \\
\hline No & 593 & $4 \cdot 4(26)$ & \multirow{3}{*}{$3 \cdot 1(0.7$ to $14 \cdot 4)$} \\
\hline Yes, before last year & 143 & $9 \cdot 1(13)$ & \\
\hline Yes, last year & 16 & $12 \cdot 5(2)$ & \\
\hline \multicolumn{4}{|l|}{ Forced to move house: } \\
\hline No & 628 & $4.5(28)$ & \multirow{3}{*}{$3.3(1.1$ to 10.1$)$} \\
\hline Yes, before last year & 94 & $9 \cdot 6(9)$ & \\
\hline Yes, last year & 30 & $13 \cdot 3(4)$ & \\
\hline \multicolumn{4}{|l|}{ Forced to change job: } \\
\hline No & 604 & $4 \cdot 6(28)$ & \multirow{3}{*}{$1 \cdot 1(0 \cdot 3$ to $5 \cdot 0)$} \\
\hline Yes, before last year & 110 & $10 \cdot 0(11)$ & \\
\hline Yes, last year & 38 & $5 \cdot 3(2)$ & \\
\hline \multicolumn{4}{|l|}{ Been made redundant: } \\
\hline No & 656 & $5 \cdot 0(33)$ & \multirow{3}{*}{$1.2(0.3$ to $5 \cdot 3)$} \\
\hline Yes, before last year & 63 & $9 \cdot 5(6)$ & \\
\hline Yes, last year & 33 & $6 \cdot 1(2)$ & \\
\hline \multicolumn{4}{|c|}{ Feelings of insecurity at work: } \\
\hline No & 527 & $4 \cdot 6(24)$ & \multirow{3}{*}{$2 \cdot 4(1 \cdot 2$ to $5 \cdot 0)$} \\
\hline Yes, before last year & 110 & $4.5(5)$ & \\
\hline Yes, last year & 115 & $10 \cdot 4(12)$ & \\
\hline \multicolumn{4}{|l|}{ Serious financial trouble: } \\
\hline No & 636 & $4 \cdot 9(31)$ & \multirow{3}{*}{$3 \cdot 0(1 \cdot 3$ to $7 \cdot 3)$} \\
\hline Yes, before last year & 64 & $4 \cdot 7(3)$ & \\
\hline Yes, last year & 52 & $13.5(7)$ & \\
\hline \multicolumn{4}{|l|}{ Been legally prosecuted: } \\
\hline No & 624 & $4 \cdot 2(26)$ & \multirow{3}{*}{$7 \cdot 7(2 \cdot 6$ to $22 \cdot 7)$} \\
\hline Yes, before last year & 108 & $9 \cdot 3(10)$ & \\
\hline Yes, last year & 20 & $25 \cdot 0(5)$ & \\
\hline
\end{tabular}

violent death while inebriated, and, in one case, pulmonary embolism in a patient with Wernicke's encephalopathy who was in an institution.

STATISTICAL METHODS

Possible associations between continuous or graded variables, or both, were tested with Pitman's nonparametric permutation test. ${ }^{33}$ Odds ratios were obtained by using conventional methods or by logistic regression ${ }^{34}$ by using the SAS statistical package (version 5.18). ${ }^{35}$

\section{Results}

Life events in the year before the baseline examination were significantly associated with mortality from all causes during follow up (table I). Of the men who had experienced three or more events $10.9 \%$ (11) had died compared with $3.3 \%$ (11) among those with no life events (odds ratio $3.6 ; 95 \%$ confidence interval 1.5 to $8 \cdot 5)$. There were 13 deaths from coronary heart disease, eight deaths from cancer, 11 deaths related to alcohol, and nine deaths from other causes. Of the specific causes of death, none was significantly associated with life events.

Table II shows the impact of separate events on mortality. Death of a family member, having been forced to change job, and redundancy did not in themselves influence mortality. Events significantly associated with mortality included serious concern about a family member, being forced to move house, feelings of insecurity at work, serious financial trouble, and an event prompting legal action.

Table III shows mean number of recent life events and influence on mortality for the many potential confounders of the association between mortality and life events. There were no significant associations between life events and serum cholesterol and triglyceride concentrations, blood pressure, or body mass 
index. These variables did not predict mortality, and they are not included in the table. Neither current smoking nor occupational class was associated with recent life events. Both variables were, however, associated with mortality. Men who claimed to experience heavy stress also had more recent life events but not higher mortality. Self perceived poor health was strongly associated with both life events and with mortality. Low social integration was associated with life events but not significantly with mortality whereas low emotional support was strongly associated with mortality but not with life events. Of the activity scales, only a low level of activity at home was associated with both life events and mortality.

In a secondary analysis to investigate whether the influence of recent life events on mortality varied according to amount of social support, mortality was calculated separately for low and high amounts of emotional support and social integration (table IV). The association between life events and mortality was evident only in men with low emotional support. For men with a high amount of emotional support there was no evidence of an effect of life events on mortality. A formal test for interaction was significant $(p=0 \cdot 008)$. The number of deaths in each cell, however, was small, and the confidence intervals were accordingly wide.

TABLE III-Mean number of recent life events and mortality from all causes by social and life style factors during seven years' follow up

\begin{tabular}{|c|c|c|c|c|c|}
\hline $\begin{array}{l}\text { Social and life } \\
\text { style factor }\end{array}$ & $\begin{array}{l}\text { No of } \\
\text { men }{ }^{\star}\end{array}$ & $\begin{array}{l}\text { Mean } \\
\text { No of } \\
\text { events }\end{array}$ & $\begin{array}{l}\mathrm{p} \text { Value } \\
\text { for } \\
\text { trend }\end{array}$ & $\begin{array}{c}\%(\mathrm{No}) \\
\text { of men who } \\
\text { died }\end{array}$ & $\mathrm{p}$ Value \\
\hline \multicolumn{6}{|l|}{ Smoking: } \\
\hline No & 479 & $1 \cdot 0$ & & $3.5(17)$ & \\
\hline Yes & 272 & $1 \cdot 1$ & $0 \cdot 29$ & $8.8(24)$ & 0.005 \\
\hline \multicolumn{6}{|l|}{ Heavy stress: } \\
\hline No & 647 & $1 \cdot 0$ & & $5 \cdot 1(33)$ & \\
\hline Yes & 101 & $1 \cdot 4$ & 0.002 & $7.9(8)$ & 0.35 \\
\hline \multicolumn{6}{|c|}{ Occupational class: } \\
\hline 0 & 58 & $1 \cdot 1$ & & $8 \cdot 6(5)$ & \\
\hline 1 & 129 & $1 \cdot 0$ & & $9 \cdot 3(12)$ & \\
\hline 2 & 169 & $1 \cdot 2$ & & $5 \cdot 3(9)$ & \\
\hline 3 & 108 & 1.0 & & $6.5(7)$ & \\
\hline 4 & 167 & $1 \cdot 1$ & & $3.0(5)$ & \\
\hline 5 & 121 & 0.9 & 0.33 & $2.5(3)$ & 0.007 \\
\hline \multicolumn{6}{|l|}{ Physical activity: } \\
\hline Sedentary & 162 & $1 \cdot 1$ & & $8 \cdot 6(14)$ & \\
\hline Other & 590 & $1 \cdot 0$ & 0.84 & $4 \cdot 6(27)$ & 0.08 \\
\hline \multicolumn{6}{|c|}{ Self perceived health: } \\
\hline Fair $(1-3)$ & 560 & 0.9 & & $3 \cdot 8(21)$ & \\
\hline Average (4) & 83 & $1 \cdot 3$ & & $8 \cdot 4(7)$ & \\
\hline Poor $(5-7)$ & 106 & 1.6 & 0.0001 & $12 \cdot 3(13)$ & 0.0006 \\
\hline \multicolumn{6}{|l|}{ Living alone: } \\
\hline Yes & 131 & $1 \cdot 2$ & & $11.5(15)$ & \\
\hline No & 604 & $1 \cdot 0$ & 0.27 & $3.8(23)$ & 0.002 \\
\hline \multicolumn{6}{|c|}{ Social integration: } \\
\hline Low & 161 & $1 \cdot 3$ & & $7 \cdot 5(12)$ & \\
\hline High & 591 & $1 \cdot 0$ & 0.001 & $4.9(29)$ & $0 \cdot 29$ \\
\hline \multicolumn{6}{|c|}{ Emotional support: } \\
\hline Low & 173 & $1 \cdot 2$ & & $10 \cdot 4(18)$ & \\
\hline High & 579 & 1.0 & $0 \cdot 11$ & $4.0(23)$ & 0.004 \\
\hline \multicolumn{6}{|l|}{ Home activities: } \\
\hline Low & 179 & $1 \cdot 2$ & & $9 \cdot 5(17)$ & \\
\hline Intermediate & 129 & $1 \cdot 2$ & & $7 \cdot 8(10)$ & \\
\hline High & 442 & 1.0 & 0.054 & $3 \cdot 2(14)$ & 0.002 \\
\hline \multicolumn{6}{|c|}{ Outside home activities: } \\
\hline Low & 186 & $1 \cdot 1$ & & $7 \cdot 0(13)$ & \\
\hline Intermediate & 130 & $1 \cdot 2$ & & $3 \cdot 8(5)$ & \\
\hline High & 436 & $1 \cdot 0$ & 0.061 & $5 \cdot 3(23)$ & 0.55 \\
\hline \multicolumn{6}{|l|}{ Social activities: } \\
\hline Low & 214 & $1 \cdot 2$ & & $6 \cdot 1(13)$ & \\
\hline Intermediate & 227 & 1.0 & & $8.4(19)$ & \\
\hline High & 309 & $1 \cdot 0$ & $0 \cdot 27$ & $2.9(9)$ & 0.092 \\
\hline
\end{tabular}

^Figures do not always equal 752 because of missing data in a few men.

TABLE IV-Mortality from all causes by social integration score and emotional support during seven years' follow up in relation to recent life events. Figures are percentages (numbers of men)

\begin{tabular}{|c|c|c|c|c|}
\hline \multirow[b]{2}{*}{ No of events } & \multicolumn{2}{|c|}{ Social integration } & \multicolumn{2}{|c|}{ Emotional support } \\
\hline & $\operatorname{Low}(n=161)$ & High $(n=591)$ & Low $(n=173)$ & High $(n=579)$ \\
\hline 0 & $0.0(0)$ & $4 \cdot 0(11)$ & $1.5(1)$ & $3 \cdot 8(10)$ \\
\hline 1 & $9 \cdot 1(4)$ & $4 \cdot 2(7)$ & $7 \cdot 7(4)$ & $4 \cdot 4(7)$ \\
\hline 2 & $15 \cdot 4(4)$ & $4 \cdot 8(4)$ & $21 \cdot 4(6)$ & $2 \cdot 4(2)$ \\
\hline$>2$ & $12 \cdot 1(4)$ & $10 \cdot 3(7)$ & $25.9(7)$ & $5 \cdot 4(4)$ \\
\hline Odds ratio $(95 \% \text { confidence interval })^{\star}$ & $7 \cdot 0(1 \cdot 4$ to $35 \cdot 6)$ & $2.5(0.9$ to 6.7$)$ & $15 \cdot 1(3.5$ to $64 \cdot 9)$ & $1.2(0.4$ to 3.8$)$ \\
\hline
\end{tabular}

${ }^{\star}$ Calculated by logistic regression.
TABLE V-Multiple logistic regression analysis with mortality from all causes as dependent variable

\begin{tabular}{lrc}
\hline Variable & \multicolumn{1}{c}{$\beta(\mathrm{SE})$} & $\mathrm{p}$ Value \\
\hline Smoking (yes $=1$, no $=0)$ & $0 \cdot 82(0.34)$ & 0.016 \\
Self perceived health $(1=$ excellent, $7=$ very poor $)$ & $0 \cdot 20(0 \cdot 10)$ & 0.054 \\
Emotional support score $(1=$ low, $2=$ high) & $-0.83(0.34)$ & 0.015 \\
Recent life events (category $0-3)$ & $0.34(0 \cdot 15)$ & 0.030 \\
\hline
\end{tabular}

TABLE VI-Crude and adjusted odds ratio for mortality from all causes by recent life events during seven years' follow up

\begin{tabular}{|c|c|c|c|}
\hline No of events & $\begin{array}{c}\%(\mathrm{No}) \\
\text { of men who died }\end{array}$ & $\begin{array}{c}\text { Crude } \\
\text { odds ratio } \\
\text { (95\% confidence } \\
\text { interval) }\end{array}$ & $\begin{array}{c}\text { Adjusted } \\
\text { odds ratio } \\
\text { (95\% confidence } \\
\text { interval })\end{array}$ \\
\hline $0(n=331)$ & $3.3(11)$ & & \\
\hline $1(\mathrm{n}=210)$ & $5 \cdot 2(11)$ & $1.6(0.7$ to 3.8$)$ & $1.6(0.7$ to 3.8$)$ \\
\hline $2(n=110)$ & $7 \cdot 3(8)$ & $2.3(0.9$ to 5.8$)$ & $1.8(0.7$ to 4.9$)$ \\
\hline 3 or more $(n=101)$ & $10.9(11)$ & $3.6(1.5$ to 8.5$)$ & $3.2(1.3$ to 7.9$)$ \\
\hline $\mathrm{p}$ Value for trend & & 0.004 & 0.030 \\
\hline
\end{tabular}

^Adjusted for smoking, emotional support, and self perceived health.

For different levels of social integration there was no evidence of an interaction effect.

In univariate analyses smoking, poor self perceived health, low occupational class, living alone, low emotional support, home activities, and life events predicted mortality. All social variables (occupational class, living alone, emotional support, and home activities) were intercorrelated and were entered separately, together with smoking, self perceived health, and life events, into logistic regression analyses. In all analyses recent life events remained a significant predictor of mortality $(p=0 \cdot 02-0 \cdot 03)$. Table $V$ shows a logistic regression analysis with mortality as the dependent variable and smoking, self perceived health, life events, and emotional support as independent variables. The association between mortality and life events was little influenced by other psychosocial factors and any combination of independent variables gave much the same result. Table VI shows crude and adjusted odds ratios for mortality from all causes in relation to life events. After emotional support, self perceived health, and smoking were controlled for there was a slight reduction in odds ratio for three events or more compared with no events.

\section{Discussion}

In previous studies, which have mostly used retrospective case-control designs, life events have been implicated as a risk factor for coronary heart disease, ${ }^{156}$ injuries in adolescence, ${ }^{37}$ breast cancer, ${ }^{38}$ and Graves' disease. ${ }^{39}$ Life events have also been associated with low social class. ${ }^{40}$ Not many prospective studies exist. Some of these have used illness or symptoms as outcome effects. ${ }^{17} 1920$ There are surprisingly few prospective studies on mortality or serious illness. Theorell et al studied several outcome variables in a large population of construction workers and found among other things that being out of work and experiencing a poor financial state predicted near future mortality. ${ }^{18} \mathrm{~A}$ single life event indicator, such as bereavement, has predicted increased mortality in men in several studies. ${ }^{84142}$ In survivors of an acute myocardial infarction, Ruberman et al found an association between life stress and subsequent mortality during a three year follow up, particularly in men who were socially isolated. ${ }^{21}$ One recent study, however, found no evidence for an influence of life events on mortality. ${ }^{25}$ This was not a general population study and men with a poor social network may have been underrepresented.

It could be argued that some of the events of the present scale are not really events, objectively seen. Items such as concern about a relative or feelings of 


\section{Public health implications}

- Life events have been used retrospectively as a measure of sources of stress in relation to health

- This prospective study looked at whether life events had an impact on mortality in middle aged men

- Life events in the year before baseline examination were significantly associated with mortality from all causes during seven years' follow up

- Adequate emotional support may protect men from the high mortality associated with stressful life events insecurity at work may be said to reflect worry rather than be truly external events. These variables were also among those which, individually, were the best predictors of mortality during follow up. This is in keeping with our previous findings from a large prospective study of a moderate but independent effect of stress on mortality. ${ }^{27}$ This finding was not replicated in the present study, probably because a large sample is needed to detect this relatively modest effect. It is, however, noteworthy that the life events which were most closely correlated with the stress variable in the present study were the same events which individually were the best predictors of mortality. Possibly our measure of life events represents a more continuous than acute harassment from adverse life circumstances. This may explain why life events during the year before the baseline examination had an effect which was measurable during a comparatively long follow up.

An obvious confounder of the association between mortality and life events which we did not measure is alcohol abuse. In our previous study on stress we were able to use classified data on alcohol abuse from the Gothenburg temperance board. The effect of stress on mortality was independent of alcohol abuse measured in this manner ${ }^{27}$ For the present study, data on alcohol abuse could no longer be obtained for legislative reasons. Many of the deaths in the present study were alcohol related, and alcohol related deaths were more common among men with many life events. There was an increase in other causes of death as well, but the lack of baseline data on alcohol in the present study is a serious problem as alcohol abuse increases mortality ${ }^{43}$ and may also increase the likelihood of adverse life events. Even so, it is equally possible that adverse life events lead to increased alcohol consumption, in which case alcohol abuse would act as a mediator in the chain of physiological events eventually leading to death.

In conclusion, adverse life events seem to have an influence on mortality for several years. Emotional support may attenuate the impact of adverse life events, although this finding must be interpreted with great caution because of the small numbers concerned. Apart from a possible role of alcohol abuse the exact mechanisms behind the increased mortality among men with many life events remain obscure. Also we cannot explain how men with adequate emotional support may be protected. The findings might be compatible with the "vulnerability hypothesis" proposed by Cassel. ${ }^{10}$ Adequate emotional support may strengthen the psychobiological resistance to stress. This study and others ${ }^{21} 44$ show the need to examine more carefully the role of interactive patterns for the effects of major life stress on health outcome.

This study was supported by the Swedish Heart and Lung Foundation (grant No 10423), The Swedish Council for Social Research, the Swedish Labour Market Insurance Company, the Swedish Medical Research Council, and the Knut and Alice Wallenberg Foundation.

1 House JS, Landis KR, Umberson D. Social relationships and health. Science $1988 ; 241: 540-5$.
2 Orth-Gomér K, Johnson JV. Social network interaction and mortality. A six year follow-up study of a random sample of the Swedish population. Fournal of Chronic Diseases 1987;40:949-57.

3 Berkman LF, Syme L. Social networks, host resistance and mortality: a nineyear follow-up study of Alameda County residents. Am f Epidemiol 1979;109:186-204

4 House JS, Robbins C, Metzner HL. The association of social relationships and activities with mortality: prospective evidence from the Tecumseh community health study. Am f Epidemiol 1982;116:123-40.

5 Marmot MG, Shipley MJ, Rose G. Inequalities in death-specific explanations of a general pattern? Lancet 1984;i:1003-6.

6 Holme I, Helgeland A, Hjermann I, Leren P, Lund-Larsen PG. Four-year mortality by some socioeconomic indicators: the Oslo study. $f$ Epidemiol Community Health 1980;34:48-52.

7 Welin L, Tibblin G, Svärdsudd K, Tibblin B, Ander-Perciva S, Larsson B, Wilhelmsen L. Prospective study of social influences on mortality. The study of men born in 1913 and 1923. Lancet 1985;i:915-8.

8 Helsing KJ, Szklo M. Mortality after bereavement. Am $\mathcal{F}$ Epidemiol 1981;114: $41-52$.

9 Holmes TH, Rahe RH. The social readjustment rating scale. $\mathcal{f}$ Psychosom Res 1967;11:213-8.

10 Cassel $\mathrm{J}$. The contribution of the social environment to host resistance. Am $\mathcal{F}$ Epidemiol 1976;104:107-23.

1 Cobb S. Social support as a moderator of life stress. Psychosom Med 1976;38:300-14

2 Theorell TGT. Review of research on life events and cardiovascular illness. Adv Cardiol 1982;29:140-7.

13 Rahe RH, Paasikivi J. Psychosocial factors and myocardial infarction. II. An outpatient study in Sweden. $\mathcal{F}$ Psychosom Res 1971;15:33-9.

14 Rahe RH, Bennett L, Romo M, Siltanen P, Arthur RJ. Subjects' recent life changes and coronary heart disease in Finland. Am $\mathcal{F}$ Psychiatry 1973;130: $1222-6$.

15 Lundberg $U$, Theorell $T$, Lind E. Life changes and myocardial infarction: individual differences in life change scaling. $¥$ Psychosom Res 1975;19:27-32.

Rahe RH, Romo M, Bennett L, Siltanen P. Recent life changes, myocardial infarction and abrupt coronary death. Arch Intern Med 1974;133:221-8.

17 Goldberg EL, Comstock GW. Life events and subsequent illness. Am f Epidemiol 1976;104:146-58.

18 Theorell T, Lind E, Flodérus B. The relationship of disturbing life-changes and emotions to the early development of myocardial infarction and other serious illnesses. Int $\mathrm{I}$ Epidemiol 1975;4:281-93.

19 Kobasa SC, Maddi SR, Courington S. Personality and constitution as mediators in the stress-illness relationship. $\mathcal{f}$ Health Soc Behav 1981;22: 368-78.

20 Billings AC, Moos RH. Stressful life events and symptoms: a longitudinal model. Health Psychol 1982;1:99-117.

21 Ruberman W, Weinblatt E, Goldberg JD, Chaudhary BS. Psychosocial influences on mortality after myocardial infarction. $N$ Engl f Med 1984:311: $552-9$

22 McFarlane AH, Norman GR, Streiner DL, Roy RG. The process of social stress: stable, reciprocal and mediating relationships. $f$ Health Soc Behav 1983;24:160-73.

23 Kasl SV. Stress and health. Annual Review of Public Health 1984;5:319-41.

24 Haney CA. Life events as precursors of coronary heart disease. Soc Sci Med 1980;14A:119-26.

25 Hollis JF, Connett JE, Stevens VJ, Greenlick MR. Stressful life events, type A behavior, and the prediction of cardiovascular and total mortality over six years. $\mathcal{F}$ Behav Med 1990;13:263-8

26 Rosengren A, Wilhelmsen L, Welin L, Tsipogianni A, Teger-Nilsson A-C, Wedel $\mathrm{H}$. Social influences and cardiovascular risk factors as determinants of plasma fibrinogen concentration in a general population sample of middle aged men. $B M F$ 1990;300:634-8.

27 Rosengren A, Tibblin G, Wilhelmsen L. Self-perceived psychological stress and incidence of coronary artery disease in middle-aged men. $\mathrm{Am} f \mathrm{Cardiol}$ 1991;68:1171-5.

28 Dohrenwend BS, Krasnoff L, Askenasy AR, Dohrenwend BP. Exemplification of a method for scaling life events: the PERI life events scale. $\mathcal{f}$ Health Soc Behav 1978;19:205-29.

29 Henderson S, Duncan-Jones P, Byrne G. Measuring social relationships. The interview schedule for social interaction. Psychol Med 1980;10:723-34.

30 Undén A-L Orth-Gomér K. Development of a social support instrument for use in population surveys. Soc Sci Med 1989;29:1387-92.

31 Statistics Sweden. Swedish socio-economic classification. Stockholm: Statistics Sweden, 1982.

32 Rosengren A, Wedel $\mathrm{H}$, Wilhelmsen L. Coronary heart disease and mortality among men from different occupational classes in Sweden. BMf 1988;297 1497-500

33 Bradley JV. Distribution-free statistical tests. Englewood Cliffs, NJ Prentice-Hall, 1968: 68-86.

34 Kleinbaum DG, Kupper LL, Morgenstern H. Epidemiologic research principles and quantitative methods. Belmont, California: Lifetime Learning Publications, 1982:422-32.

35 SAS Institute. SAS user's guide: statistics. Version 5.18. Cary, NC: SAS Institute, 1985.

36 Thiel HG, Parker D, Bruce TA. Stress factors and the risk of myocardial infarction. F Psychosom Res 1973;17:43-57.

37 Slap GB, Chaudhuri S, Vorters DF. Risk factors for injury during adolescence. f Adolesc Health 1991;12:263-8.

38 Forsen A. Psychosocial stress as a risk for breast cancer. Psychother Psychosom 1991;55:176-85.

39 Winsa B, Adami H-O, Bergström R, Gamstedt A, Dahlberg PA, Adamson U, et al. Stressful life events and Graves' disease. Lancet 1991;338:1475-9.

40 Marmot MG, Davey Smith G, Stansfeld S, Patel C, North F, Head J, et al. Health inequalities among British civil servants: the Whitehall II study. Lancet 1991;337:1387-93.

41 Mellström D, Nilsson $\AA$, Odén A, Rundgren $\AA$, Svanborg A. Mortality among the widowed in Sweden. Scand F Soc Med 1982;10:33-41

42 Jones DR. Heart disease mortality following widowhood: some results from the OPCS longitudinal study. F Psychosom Res 1987;31:325-33.

43 Rosengren A, Wilhelmsen L, Pennert K, Berglund G, Elmfeldt D. Alcohol intemperance, coronary heart disease, and mortality in middle aged Swedish men. Acta Medica Scandinavica 1987;222:201-13.

44 Orth-Gomér K, Undén A-L. Type A behavior, social support and coronary risk. Interaction and significance for mortality in cardiac patients. Psychosom Med 1990;52:59-72.

(Accepted 20 August 1993) 